ISSN 1392-3196 / e-ISSN 2335-8947

Zemdirbyste-Agriculture, vol. 104, No. 1 (2017), p. 71-78

DOI 10.13080/z-a.2017.104.010

\title{
The sensitivity of Lolium perenne and Poa pratensis to salinity and drought during the seed germination and under different photoperiod conditions
}

\author{
Barbara BORAWSKA-JARMUŁOWICZ ${ }^{1}$, Grażyna MASTALERCZUK ${ }^{1}$, \\ Dariusz GOZDOWSKI ${ }^{1}$, Elżbieta MAŁUSZYŃSKA ${ }^{2}$, Anna SZYDŁOWSKA ${ }^{2}$ \\ ${ }^{1}$ Warsaw University of Life Sciences \\ Nowoursynowska 159, 02-779 Warsaw, Poland \\ E-mail: barbara_borawska_jarmulowicz@sggw.pl \\ ${ }^{2}$ The Plant Breeding and Acclimatization Institute (IHAR) - National Research Institute \\ Radzików, 05-870 Błonie, Poland
}

\begin{abstract}
Salinity and drought are the main factors limiting the germination of seeds and development of lawn grasses. The study, carried out in controlled conditions, explored the effects of salt and drought stress as well as photoperiod on germination and morphological traits of seedlings of perennial ryegrass (Lolium perenne L.) and Kentucky bluegrass (Poa pratensis L.) lawn varieties. Germination capacity and mean germination time of seeds as well as the length and dry mass of shoots and roots of seedlings were determined. The germination of seeds was conducted on three levels of sodium chloride $(\mathrm{NaCl})$ salinity $(0,100$ and $200 \mathrm{mM})$ and four levels of drought stress using polyethylene glycol (PEG) solutions $(0,-0.3,-0.6$ and $-1.2 \mathrm{MPa})$ in different photoperiod $(0,8$ and $12 \mathrm{~h}$ of light) and temperature conditions (constant $25^{\circ} \mathrm{C}$ and variable $30 / 20^{\circ} \mathrm{C}$ ). The obtained results showed that salinity decreased the germination capacity, the length of seedling shoots and roots, number of roots and dry mass of shoots and increased mean germination time (MGT) of seeds, especially of P. pratensis varieties. Drought stress increased mean germination time and limited germination capacity, shoot and root length and dry mass of $L$. perenne varieties only under the highest $-1.2 \mathrm{MPa}$ level, whereas $P$. pratensis - even at $-0.3 \mathrm{MPa}$. In the conditions of salinity and simulated drought, germination capacity, shoot and root length and the mass of shoots of $L$. perenne and $P$. pratensis seedlings were closely correlated to each other. The results of this study indicate that germination capacity of $P$. pratensis varieties was modified by light duration. This species proved to be intolerant of lack of light during seed germination, while L. perenne varieties showed tolerance to photoperiod in this stage.
\end{abstract}

Key words: drought tolerance, gravimetric parameters, Kentucky bluegrass, lawn grasses, morphological parameters, $\mathrm{NaCl}$, perennial ryegrass, photoperiod, polyethylene glycol.

\section{Introduction}

Perennial ryegrass (Lolium perenne L.) and Kentucky bluegrass (Poa pratensis L.) are the most widely used cool-season lawn grasses. These species can be used not only on home lawns, but sports fields and urban green areas as well if they are properly utilized (Żurek, 2006). Many stresses, especially salinity and drought, are the main factors limiting the germination of seeds and development of plants.

The state of salinity is important for seeds of grass species and varieties that are used in mixtures to establish street lawns of towns and green belts along traffic arteries because of using sand and chloride salts to fight the after-snow slippery state of roads in winter time. In Poland, in these conditions the use of sodium chloride is frequent and high (Borowski, 2008 a). Accumulation of products containing chloride salts in roadside soils may create conditions unsuitable for the growth of many plant species (White, Broadley, 2001) and plants respond to salinity with the inhibition of growth rate and biomass production (Khaleghi, Ramin, 2005; Abbassi et al., 2016). Sodium chloride has been defined as the most harmful for plants from the analyzed road de-icing substances (Wrochna et al., 2010). Presence of excessive salt $(\mathrm{NaCl})$ outside the cell can induce an osmotic stress limiting water uptake, which may adversely affect the plant growth and development (Muns, Tester, 2008). High levels of salts in the soil can disrupt osmotic balance in the rhizosphere, making water less available to plants. Chloride ion $\left(\mathrm{Cl}^{-}\right)$is taken up by the plant roots and can accumulate in the leaves of many plants (White, Broadley, 2001). The share of grasses in street lawns is rather small under salinity conditions (only about $40 \%$ of plants cover). Among them Festuca rubra, L. perenne and P. pratensis proved to be most useful for the establishment 
of lawns (Stawicka et al., 2006). The seeds at germination are most susceptible to salinity stress and studies in this field indicate considerable differentiation of grass seeds within the species and varieties in tolerating salinity (Hujun et al., 2001; Jalali et al., 2010). According to Dai et al. (2009), the germination of several cool-season turfgrass species showed $L$. perenne to be relatively the most salt-tolerant while $P$. pratensis the least. However, the existing results do not give complete information on this subject. In determining the viability of seeds it is important to assess the rate and energy of germination, because the seeds of a better vigour have a greater tolerance of unfavourable habitat conditions (BorawskaJarmułowicz, Mastalerczuk, 2010). Plant response to stress conditions during the germination of seeds does not necessarily correlate with vegetative growth. Literature suggests that in the seedling stage varieties of L. perenne show different tolerance of salinity stress (Hujun et al., 2001; Borowski, 2008 a; b; Kusvuran et al., 2015) whereas $P$. pratensis should be pointed as moderately sensitive (Friell et al., 2013). Because of that, screening and breeding cool-season turfgrass varieties that are salttolerant during both seed germination and vegetative growth becomes important (Dai et al., 2009). Literature shows that seed germination is tested over a wide range of various germination media, salt concentrations as well as experimental temperatures and light intensity (Yuan, Shi, 2009; Zhang et al., 2011; 2012; Dudley et al., 2014). According to Zhang et al. (2012), temperature and salinity have complex interactions; increased temperature is able to partially or fully compensate for growth reduction under saline conditions.

Cool-season lawn grasses often suffer from extended periods of drought stress during summer months. Drought has become more common in recent years due to global climate change. Therefore the knowledge of relative drought resistance is important for selecting of lawn grass varieties that can survive during drought period (Chai et al., 2006). One of the laboratory methods used in assessing the reaction of plants to drought is a method of seed germination under conditions of negative water potential. The use of solutions with a negative potential (polyethylene glycol, PEG) obtained upon addition of osmotically active substances to water enables the laboratory simulation of natural water shortage in the environment (Hardegree, Emmerich, 1994). Tests of seed germination in these conditions are treated as authoritative method for assessing the resistance of seeds to water scarcity during germination and can be a source of information about the potential reaction of varieties of grasses to drought (Żurek, 2006). The mean germination time is recognized as an indicator of viability and seed vigour which is visible in the subsequent ontogeny of plants (Ellis, Roberts, 1980).

Studies concerning the seed germination of grasses under stress conditions are conducted on the basis of different methods. The proper method of seed germination should be chosen based on required purpose and facilities with understanding the influence of different germination methods on salinity and drought tolerance of lawn grasses. Studies on the influence of light conditions on the lawn varieties of grasses concerned only vegetative stage (Dąbrowski et al., 2015), while there is little information about the impact of light on their seed germination (Borawska-Jarmułowicz, Mastalerczuk, 2010). For this reason, the purpose of the present study was to estimate the effect of salinity and drought stress levels as well as light conditions on seed germination and initial seedling growth of common lawn grass species perennial ryegrass (Lolium perenne L.) and Kentucky bluegrass (Poa pratensis L.).

\section{Materials and methods}

The study evaluated the effects of sodium chloride $(\mathrm{NaCl})$ salinity and drought induced by polyethylene glycol (PEG) 6000 on the germination and seedling growth of Polish lawn varieties of two common grass species, used on near-road areas: perennial ryegrass (Lolium perenne L.) - 'Bokser', 'Stadion' and Kentucky bluegrass (Poa pratensis L.) - 'Bila', 'Sójka'. Research was carried out in 2014 in two separate experiments (salt and drought stress) repeated twice in programmed thermostat POL EKO ST 600 (POL-EKO Aparatura, Poland) in different conditions of germination. The analysis of seed purity was performed according to ISTA Rules (2014) and for the seeds of $P$. pratensis the uniform blowing method was applied. Seed purity of L. perenne varieties was $99.1-99.7 \%$ and a 1000 seed mass varied from 1.747 to $1.953 \mathrm{~g}$ ('Bokser' and 'Stadion', respectively). Purity of $P$. pratensis seeds of var. 'Sójka' and 'Bila' was 97.9-98.3\% and a 1000 seed mass was 0.290 and $0.342 \mathrm{~g}$, respectively. Seeds were initially treated with a $70 \%$ solution of ethanol for 2 minutes for surface sterilization, rinsed with distilled water three times, and then quickly dried with a paper tissue. Seed germination conditions were established according to ISTA Rules (2014).

Germination according to the ISTA Rules (2014). Germination tests to assess germination capacity of investigated varieties were carried out in accordance with different temperature and light conditions: $30 / 20^{\circ} \mathrm{C}$ (day/night) temperature regime and $8 / 16 \mathrm{~h}$ (day/night) photoperiod under cool, white light $20 \mathrm{~W} \mathrm{~m}^{-2}$. Three replicates of 50 seeds of each variety were placed in a square plastic box (capacity 0.81 ) containing three layers of filter paper $\left(65 \mathrm{~g} \mathrm{~m}^{-2}\right)$ moistened with distilled water (60\% compared to control volume of the water).

Germination under salt stress. Germination capacity was estimated in constant temperature $25^{\circ} \mathrm{C}$ (day/night) under cool, white light $20 \mathrm{~W} \mathrm{~m}^{-2}$ and variable photoperiod 12/12 h (day/night). Three replicates of 50 seeds of each variety were placed in plastic boxes containing three layers of filter paper moistened in solution of three salt concentrations $(\mathrm{mM} \mathrm{NaCl}): 0,100$ and 200 (Borowski, 2008 a).

Germination under drought stress. Germination capacity was carried out in analogous light and temperature conditions as the salt stress. Drought stress was simulated by using the solutions of polyethylene glycol (PEG) 6000, which resulted in retention of its molecules outside the cell walls, because of its high molecular weight. The amount of PEG applied to create each level of drought stress was mixed with water obtaining osmotic potential of: 0.0 (deionized water), $-0.3,-0.6$ and $-1.2 \mathrm{MPa}$ (Hardegree, Emmerich, 1994), measured with a cryoscopic osmometer Osmomat 030 (Gonotec GmbH, Germany). There were three replicates of 50 seeds per variety and treatment.

Mean germination time (MGT) under stress conditions. The studies were carried out in analogous salt and drought stress levels at the constant temperature 
of $25^{\circ} \mathrm{C}$ under exposure to dark conditions $(0 / 24 \mathrm{~h}$ photoperiod) (Ellis, Roberts, 1980). Three replicates of 50 seeds of investigated varieties were germinated on 10-diameter Petri dishes laid with two layers of moistened filter paper. To avoid seed float on the surface of the solution, the filter paper was planted into plastic disc with a thickness of approx. $3 \mathrm{~mm}$. In order to prevent the evaporation during germination of seed, in each experiment the boxes and Petri dishes were put into airtight transparent plastic bags.

Measurements. Germination capacity data were collected based on the final counts of normal seedlings after 10 days for $L$. perenne and 21 days for $P$. pratensis. Seedlings were scored as normal as defined by ISTA Rules (2014) and Handbook of Seedling Evaluation (2013), as type D group A 1-2-3-1. MGT in both stress conditions was determined every day from the beginning to the end of germination. In stress conditions, because of slow germination of seeds, it was conducted over a longer period than foreseen in the Rules of ISTA. The number of germinated seeds was determined, considering the seeds with radicle $2 \mathrm{~mm}$ long. Then the germinated seeds were removed from Petri dishes. The mean germination time was calculated on the basis of the number of germinated seeds as follows (Ellis, Roberts, 1980): MGT (day) $=\sum(\mathrm{fx}) / \sum \mathrm{f}$, where $\mathrm{x}$ is the day of counting, $\mathrm{f}-$ the number of newly germinated seeds on each day.

To estimate morphological parameters of tested varieties twenty normal seedlings were sampled randomly from each plastic box in the end of study, according to the ISTA Rules (2014) as well as salinity and drought conditions. The length of shoots and roots of seedlings as well as the number of roots was determined. The distance from the crown to leaf tip and root tip was measured as the shoot and root length, respectively. Then the seedlings were separated into roots and shoots and their dry mass was evaluated after drying in an oven at $80^{\circ} \mathrm{C}$ for $24 \mathrm{~h}$ to a constant weight. The obtained results were expressed per seedling (mg per plant); the ratio of root to shoot (R:S) mass was also estimated.

Statistical analysis. The presented data are the mean values from experiments repeated twice. Comparisons of means were performed on the basis of twoway analysis of variance and multiple comparisons based on LSD. Pearson's correlations were used for evaluation of relationships between pairs of variables. The analyses were conducted using statistical program Statistica, version 12 (StatSoft Inc., USA). For all analyses significance level was set at $P \leq 0.05$. For the evaluation of relationships between all traits across cultivars and treatments, principal component analysis (PCA) was conducted. The results of PCA were presented as a biplot of the first and the second principal components (PC1 and PC2).

\section{Results and discussion}

Effect of salinity on seed germination. Germination capacity of $L$. perenne varieties in conditions without salt stress was similar: ranged from $87 \%$ ('Bokser') to $96 \%$ ('Stadion'), according to ISTA Rules (2014): day/night $30 / 20^{\circ} \mathrm{C}$ temperature regime and $8 / 16 \mathrm{~h}$ photoperiod, as well as at constant temperature $\left(25^{\circ} \mathrm{C}\right)$ in the dark and also with $12 \mathrm{~h}$ exposure to light (Table 1). At the same time, the obtained results showed that seed germination of $P$. pratensis varieties was highly affected by light. Germination capacity of both varieties 'Bila' and 'Sójka' significantly decreased in the dark. Our previous studies have demonstrated positive effect of longer day conditions on seed vigour of $P$. pratensis varieties, while the germination capacity varied (Borawska-Jarmułowicz, Mastalerczuk, 2010). According to Yuan and Shi (2009), germination tolerance for light intensity is expected for some grass species in natural environment where seeds could be exposed to different light regimes, ranging from full light to dark. In salinity conditions the two investigated species had also different response to stress. L. perenne varieties showed a decrease of seed germination only at the highest level of salinity (200 mM NaCl), especially var. 'Bokser'. Variety 'Stadion' characterized by high germination in this solution (approx. 89\%) demonstrating salt tolerance in the period of seed germination. It is in agreement with the previous study of Dai et al. (2009), who stated that $L$. perenne was relatively the most salt-tolerant among the tested several cool-season turfgrass species. Our results have been confirmed in the studies by Kusvuran et al. (2015), who found that salt stress caused $17 \%$ reductions in germination in the turfgrass varieties of $L$. perenne with the $200 \mathrm{mM} \mathrm{NaCl}$ treatment. Borowski (2008 a) found out strong inhibition of the germination of $L$. perenne seeds in this salinity conditions as well. According to the results of our study, varieties of $P$. pratensis were less tolerant of salt stress conditions than those of $L$. perenne. It was noted that under lower salinity level $(100 \mathrm{mM}$ $\mathrm{NaCl})$ germinated only var. 'Bila'. These results agree with Friell et al. (2013) investigations which showed the least salt tolerance of $P$. pratensis varieties compare to other lawn grasses.

Evaluation of MGT of seeds carried out in the dark at $25^{\circ} \mathrm{C}$ showed a large variation between the assessed varieties and the salinity levels (Table 2). In the conditions without salt addition, $L$. perenne varieties were characterized by shorter MGT of seeds, whereas $P$. pratensis seeds showed a diverse time of germination under these conditions. Variety 'Sójka' germinated significantly longer than var. 'Bila' $(6.5$ and 11 days, respectively). It should be also noted that MGT of all

Table 1. Germination capacity (\%) of Lolium perenne and Poa pratensis varieties in different temperature, photoperiod and salinity levels

\begin{tabular}{|c|c|c|c|c|c|c|c|c|}
\hline \multicolumn{2}{|c|}{ Germination conditions } & \multirow{2}{*}{$\begin{array}{c}\text { Salinity level } \\
\mathrm{mM} \mathrm{NaCl}\end{array}$} & \multicolumn{2}{|c|}{ L. perenne } & \multicolumn{2}{|c|}{ P. pratensis } & \multirow{2}{*}{ L. perenne } & \multirow{2}{*}{ P. pratensis } \\
\hline Day/night & Light/dark & & 'Bokser' & 'Stadion' & 'Bila' & 'Sójka' & & \\
\hline $30 / 20^{\circ} \mathrm{C}$ & $8 / 16 \mathrm{~h}$ & 0 & $88.7 \mathrm{~b}$ & $96.0 \mathrm{~b}$ & $71.3 \mathrm{~d}$ & $86.0 \mathrm{e}$ & $92.3 \mathrm{D}$ & $78.7 \mathrm{D}$ \\
\hline $25 / 25^{\circ} \mathrm{C}$ & $0 / 24 \mathrm{~h}$ & 0 & $86.7 \mathrm{~b}$ & $94.0 \mathrm{~b}$ & $11.3 \mathrm{~b}$ & $0.7 \mathrm{a}$ & $90.3 \mathrm{D}$ & $6.0 \mathrm{~A}$ \\
\hline $25 / 25^{\circ} \mathrm{C}$ & $12 / 12 \mathrm{~h}$ & 0 & $89.3 \mathrm{~b}$ & $95.3 \mathrm{~b}$ & $70.0 \mathrm{~d}$ & $17.3 \mathrm{~b}$ & $92.3 \mathrm{D}$ & $43.7 \mathrm{C}$ \\
\hline $25 / 25^{\circ} \mathrm{C}$ & $12 / 12 \mathrm{~h}$ & 100 & $92.7 \mathrm{~b}$ & $91.3 \mathrm{~b}$ & $52.0 \mathrm{c}$ & $0.0 \mathrm{a}$ & $92.0 \mathrm{D}$ & $26.0 \mathrm{~B}$ \\
\hline $25 / 25^{\circ} \mathrm{C}$ & $12 / 12 \mathrm{~h}$ & 200 & $68.7 \mathrm{a}$ & $88.7 \mathrm{~b}$ & $0.0 \mathrm{a}$ & $0.0 \mathrm{a}$ & $78.7 \mathrm{D}$ & $0.0 \mathrm{~A}$ \\
\hline
\end{tabular}

Note. Mean values within varieties of the same species followed by the same lowercase letter are not significantly $(P \leq 0.05)$ different; mean values within species followed by the same uppercase letter are not significantly $(P \leq 0.05)$ different. 
Table 2. Mean germination time (days) of Lolium perenne and Poa pratensis varieties under salinity conditions at $25^{\circ} \mathrm{C}$ and $0 / 24 \mathrm{~h}$ photoperiod

\begin{tabular}{cccccc}
\hline \multirow{2}{*}{$\begin{array}{c}\text { Salinity level } \\
\text { mM NaCl }\end{array}$} & \multicolumn{2}{c}{ L. perenne } & \multicolumn{2}{c}{ P.pratensis } & L. perenne \\
\cline { 2 - 5 } 'Bokser' & 'Stadion' & 'Bila' & 'Sójka' & \\
\hline 0 & $3.4 \mathrm{a}$ & $3.1 \mathrm{a}$ & $6.5 \mathrm{~b}$ & $11.0 \mathrm{c}$ & $3.2 \mathrm{~A}$ \\
100 & $5.2 \mathrm{~b}$ & $4.5 \mathrm{~b}$ & $11.7 \mathrm{c}$ & $12.0 \mathrm{c}$ & $4.9 \mathrm{AB}$ \\
200 & $12.4 \mathrm{~d}$ & $10.0 \mathrm{c}$ & $17.3 \mathrm{~d}$ & $0.0 \mathrm{a}$ & $11.8 \mathrm{~B}$ \\
\hline
\end{tabular}

Explanation under Table 1

varieties increased under conditions of salinity. It was found that in conditions of higher salinity $(200 \mathrm{mM}$ $\mathrm{NaCl}$ ) var. 'Bokser' germinated significantly longer than var. 'Stadion'. The obtained results are in agreement with those reported by Nizam (2011), who stated that MGT of $L$. perenne was significantly increased by salinity. In such conditions, as a result of increasing osmotic pressure, water uptake is delayed and germination time is longer. In our study, MGT of $P$. pratensis var. 'Bila' under higher salinity level was 17 days while var. 'Sójka' did not germinate.

Effect of salinity on seedling growth. Shoot and root length of evaluated species and varieties was significantly affected by different conditions of germination and salinity levels (Table 3 ). It was found that in conditions without stress only varieties of L. perenne formed significantly longer shoots in comparison to conditions with variable temperature and light, according to ISTA Rules (2014). Despite above, it was noticed that salinity had more negative effects on growth of P. pratensis plants than on L. perenne. Concentration of $100 \mathrm{mM} \mathrm{NaCl}$ resulted in significantly shorter shoots of $P$. pratensis var. 'Bila' (var. 'Sójka' did not germinate) while shoot length of both $L$. perenne varieties decreased only under the highest applied salinity level $(200 \mathrm{mM})$. Root length of $L$. perenne decreased with increasing salinity. Among varieties of L. perenne 'Stadion' had longer shoots and roots than var. 'Bokser'. Our results

Table 3. Morphological features of seedlings of Lolium perenne and Poa pratensis varieties under salinity conditions

\begin{tabular}{|c|c|c|c|c|c|c|c|c|}
\hline \multicolumn{2}{|c|}{ Germination conditions } & \multirow{2}{*}{$\begin{array}{c}\text { Salinity level } \\
\mathrm{mM} \mathrm{NaCl}\end{array}$} & \multicolumn{2}{|c|}{ L. perenne } & \multicolumn{2}{|c|}{ P. pratensis } & \multirow{2}{*}{ L. perenne } & \multirow{2}{*}{ P. pratensis } \\
\hline Day/night & Light/dark & & 'Bokser' & 'Stadion' & 'Bila' & 'Sójka' & & \\
\hline \multicolumn{9}{|c|}{ Shoot length mm } \\
\hline $30 / 20^{\circ} \mathrm{C}$ & $8 / 16 \mathrm{~h}$ & 0 & $63.5 \mathrm{~b}$ & $72.1 \mathrm{c}$ & $30.7 \mathrm{c}$ & $26.0 \mathrm{~b}$ & $67.8 \mathrm{E}$ & $28.4 \mathrm{BC}$ \\
\hline $25 / 25^{\circ} \mathrm{C}$ & $12 / 12 \mathrm{~h}$ & 0 & $71.6 \mathrm{c}$ & $83.1 \mathrm{~d}$ & $32.6 \mathrm{c}$ & $23.3 \mathrm{~b}$ & $77.3 \mathrm{~F}$ & $29.8 \mathrm{C}$ \\
\hline $25 / 25^{\circ} \mathrm{C}$ & $12 / 12 \mathrm{~h}$ & 100 & $74.1 \mathrm{c}$ & $77.4 \mathrm{~cd}$ & $24.8 \mathrm{~b}$ & $0.0 \mathrm{a}$ & $75.8 \mathrm{~F}$ & $23.6 \mathrm{~B}$ \\
\hline $25 / 25^{\circ} \mathrm{C}$ & $12 / 12 \mathrm{~h}$ & 200 & $48.4 \mathrm{a}$ & $49.3 \mathrm{a}$ & $0.0 \mathrm{a}$ & $0.0 \mathrm{a}$ & $48.8 \mathrm{D}$ & $0.0 \mathrm{~A}$ \\
\hline \multicolumn{9}{|c|}{ Root length $\mathrm{mm}$} \\
\hline $30 / 20^{\circ} \mathrm{C}$ & $8 / 16 \mathrm{~h}$ & 0 & $65.9 \mathrm{~d}$ & $73.5 \mathrm{e}$ & $27.8 \mathrm{c}$ & $40.1 \mathrm{~d}$ & $69.7 \mathrm{~F}$ & $33.9 \mathrm{C}$ \\
\hline $25 / 25^{\circ} \mathrm{C}$ & $12 / 12 \mathrm{~h}$ & 0 & $63.4 \mathrm{~cd}$ & $67.6 \mathrm{de}$ & $35.1 \mathrm{~d}$ & $32.5 \mathrm{~cd}$ & $65.5 \mathrm{~F}$ & $34.3 \mathrm{CD}$ \\
\hline $25 / 25^{\circ} \mathrm{C}$ & $12 / 12 \mathrm{~h}$ & 100 & $51.0 \mathrm{~b}$ & $57.6 \mathrm{c}$ & $19.5 \mathrm{~b}$ & $0.0 \mathrm{a}$ & $54.3 \mathrm{E}$ & $18.6 \mathrm{~B}$ \\
\hline $25 / 25^{\circ} \mathrm{C}$ & $12 / 12 \mathrm{~h}$ & 200 & $36.1 \mathrm{a}$ & $41.6 \mathrm{a}$ & $0.0 \mathrm{a}$ & $0.0 \mathrm{a}$ & $38.8 \mathrm{D}$ & $0.0 \mathrm{~A}$ \\
\hline \multicolumn{9}{|c|}{ Number of roots } \\
\hline $30 / 20^{\circ} \mathrm{C}$ & $8 / 16 \mathrm{~h}$ & 0 & $2.4 \mathrm{e}$ & $2.2 \mathrm{de}$ & $1.0 \mathrm{~b}$ & $1.3 \mathrm{~cd}$ & $2.1 \mathrm{E}$ & $1.4 \mathrm{C}$ \\
\hline $25 / 25^{\circ} \mathrm{C}$ & $12 / 12 \mathrm{~h}$ & 0 & $2.3 \mathrm{de}$ & $2.0 \mathrm{bcd}$ & $1.5 \mathrm{~d}$ & $1.2 \mathrm{bc}$ & $2.3 \mathrm{E}$ & $1.2 \mathrm{BC}$ \\
\hline $25 / 25^{\circ} \mathrm{C}$ & $12 / 12 \mathrm{~h}$ & 100 & 2.0 cde & $1.7 \mathrm{bc}$ & $1.1 \mathrm{~b}$ & $0.0 \mathrm{a}$ & $1.8 \mathrm{D}$ & $1.0 \mathrm{~B}$ \\
\hline $25 / 25^{\circ} \mathrm{C}$ & $12 / 12 \mathrm{~h}$ & 200 & $1.6 \mathrm{~b}$ & $1.2 \mathrm{a}$ & $0.0 \mathrm{a}$ & $0.0 \mathrm{a}$ & $1.4 \mathrm{C}$ & $0.0 \mathrm{~A}$ \\
\hline
\end{tabular}

Explanation under Table 1

are consistent with those of other recent studies which have shown that the growth of plants is negatively impacted by salt concentrations, and root length of L. perenne decreases linearly with increasing salinity levels (Borowski, 2008 a; Pessarakli, Kopec, 2009; Nizam, 2011). It was noticed that without salt stress conditions $L$. perenne varieties developed significantly more roots (2-times) than varieties of $P$. pratensis. Salinity reduced the number of roots formed by the grass seedlings. With increasing level of salt stress the number of roots distinctly decreased, especially at $200 \mathrm{mM} \mathrm{NaCl}$, in relation to other conditions. Nizam (2011) reported that root number of lawn grass species increases till 100 $\mathrm{mM}$ salinity level, at a higher level of salinity plants form fewer roots. There was found a significant and positive correlation $(r=0.64, P \leq 0.05)$ between the leaf and root length of the tested varieties.

Mass of shoots and roots of $L$. perenne and $P$. pratensis seedlings varied depending on the germination conditions and salt level (Table 4). Higher shoot dry mass was obtained under the conditions without salt addition. This was particularly evident for varieties of L. perenne which developed significantly lower biomass of shoots at $200 \mathrm{mM}$ salinity compared to other conditions (P. pratensis varieties did not germinate). According to Kusvuran et al. (2015), plant growth of varieties of L. perenne was significantly reduced under salinity of $200 \mathrm{mM} \mathrm{NaCl}$. Our data showed that under this salinity level the root mass of $L$. perenne varieties increased. As a result, var. 'Stadion' showed the highest (significant) root to shoot (R:S) ratio. Dai et al. (2009) reported that root dry mass of $L$. perenne declined with increasing salinity. In the study of Nizam (2011) low salinity level did not change significantly the mass of roots. The results presented demonstrate significant correlation between shoot and root mass only for var. 'Sójka' of $P$. pratensis $(r=0.99, P \leq 0.05)$ under $0 \mathrm{mM} \mathrm{NaCl}$. Taking into account our results, $L$. perenne appears to be more salt tolerant species during the seed germination and seedling growth while $P$. pratensis being the most sensitive to such stress. It is in agreement with previous studies of Zhang and Rue (2012) who investigated salinity and osmotic tolerance in turfgrasses. This indicates that in areas at a low chloride ion concentration, varieties of $P$. pratensis could be used. However, in the conditions of high concentrations of salt, mixtures with varieties of $L$. perenne, relatively tolerant to these conditions, could be most effective. 
Table 4. Shoot and root dry mass of seedlings of Lolium perenne and Poa pratensis varieties under salinity conditions

\begin{tabular}{|c|c|c|c|c|c|c|c|c|}
\hline \multicolumn{2}{|c|}{ Germination conditions } & \multirow{2}{*}{$\begin{array}{c}\text { Salinity level } \\
\mathrm{mM} \mathrm{NaCl}\end{array}$} & \multicolumn{2}{|c|}{ L. perenne } & \multicolumn{2}{|c|}{ P. pratensis } & \multirow{2}{*}{ L. perenne } & \multirow{2}{*}{ P. pratensis } \\
\hline Day/night & Light/dark & & 'Bokser' & 'Stadion' & 'Bila' & 'Sójka' & & \\
\hline \multicolumn{9}{|c|}{ Shoot dry mass mg per plant } \\
\hline $30 / 20^{\circ} \mathrm{C}$ & $8 / 16 \mathrm{~h}$ & 0 & $5.33 \mathrm{c}$ & $5.97 \mathrm{~d}$ & $0.54 \mathrm{c}$ & $0.64 \mathrm{~d}$ & $5.65 \mathrm{G}$ & $0.59 \mathrm{C}$ \\
\hline $25 / 25^{\circ} \mathrm{C}$ & $12 / 12 \mathrm{~h}$ & 0 & $4.63 \mathrm{~b}$ & $5.45 \mathrm{~cd}$ & $0.43 \mathrm{~b}$ & $0.55 \mathrm{~cd}$ & $5.04 \mathrm{~F}$ & $0.49 \mathrm{BC}$ \\
\hline $25 / 25^{\circ} \mathrm{C}$ & $12 / 12 \mathrm{~h}$ & 100 & $4.38 \mathrm{~b}$ & $4.35 \mathrm{~b}$ & $0.38 \mathrm{~b}$ & $0.00 \mathrm{a}$ & $4.37 \mathrm{E}$ & $0.19 \mathrm{AB}$ \\
\hline $25 / 25^{\circ} \mathrm{C}$ & $12 / 12 \mathrm{~h}$ & 200 & $2.88 \mathrm{a}$ & $3.02 \mathrm{a}$ & $0.00 \mathrm{a}$ & $0.00 \mathrm{a}$ & $2.95 \mathrm{D}$ & $0.00 \mathrm{~A}$ \\
\hline \multicolumn{9}{|c|}{ Root dry mass mg per plant } \\
\hline $30 / 20^{\circ} \mathrm{C}$ & $8 / 16 \mathrm{~h}$ & 0 & $0.18 \mathrm{ab}$ & $0.57 \mathrm{c}$ & $0.01 \mathrm{~b}$ & $0.02 \mathrm{c}$ & $0.38 \mathrm{C}$ & $0.02 \mathrm{~A}$ \\
\hline $25 / 25^{\circ} \mathrm{C}$ & $12 / 12 \mathrm{~h}$ & 0 & $0.07 \mathrm{a}$ & $0.05 \mathrm{a}$ & $0.03 \mathrm{~cd}$ & $0.03 \mathrm{~d}$ & $0.06 \mathrm{~A}$ & $0.03 \mathrm{~A}$ \\
\hline $25 / 25^{\circ} \mathrm{C}$ & $12 / 12 \mathrm{~h}$ & 100 & $0.05 \mathrm{a}$ & $0.08 \mathrm{a}$ & $0.03 \mathrm{~d}$ & $0.00 \mathrm{a}$ & $0.07 \mathrm{~A}$ & $0.02 \mathrm{~A}$ \\
\hline $25 / 25^{\circ} \mathrm{C}$ & $12 / 12 \mathrm{~h}$ & 200 & $0.12 \mathrm{ab}$ & $0.32 \mathrm{~b}$ & $0.00 \mathrm{a}$ & $0.00 \mathrm{a}$ & $0.22 \mathrm{~B}$ & $0.00 \mathrm{~A}$ \\
\hline \multicolumn{9}{|c|}{$\mathrm{R}: \mathrm{S}$ ratio } \\
\hline $30 / 20^{\circ} \mathrm{C}$ & $8 / 16 \mathrm{~h}$ & 0 & $0.03 \mathrm{a}$ & $0.09 \mathrm{~b}$ & $0.02 \mathrm{~b}$ & $0.03 \mathrm{~b}$ & $0.06 \mathrm{D}$ & $0.03 \mathrm{ABC}$ \\
\hline $25 / 25^{\circ} \mathrm{C}$ & $12 / 12 \mathrm{~h}$ & 0 & $0.01 \mathrm{a}$ & $0.01 \mathrm{a}$ & $0.06 \mathrm{c}$ & $0.05 \mathrm{c}$ & $0.01 \mathrm{AB}$ & $0.06 \mathrm{CD}$ \\
\hline $25 / 25^{\circ} \mathrm{C}$ & $12 / 12 \mathrm{~h}$ & 100 & $0.01 \mathrm{a}$ & $0.02 \mathrm{a}$ & $0.08 \mathrm{~d}$ & $0.00 \mathrm{a}$ & $0.02 \mathrm{AB}$ & $0.04 \mathrm{BCD}$ \\
\hline $25 / 25^{\circ} \mathrm{C}$ & $12 / 12 \mathrm{~h}$ & 200 & $0.04 \mathrm{a}$ & $0.10 \mathrm{~b}$ & $0.00 \mathrm{a}$ & $0.00 \mathrm{a}$ & $0.07 \mathrm{D}$ & $0.00 \mathrm{~A}$ \\
\hline
\end{tabular}

Explanation under Table 1

Principle component analysis (PCA) in salinity conditions indicated that the first component (PC1) related to the dry mass of roots retained $80.5 \%$ (Fig. 1). PCA showed that the length of shots and roots, the mass of shoots and germination capacity were closely correlated to each other. Variety 'Stadion' of $L$. perenne in conditions without salt at variable temperature and photoperiod was characterized by high values of all the traits, particularly high mass of roots.

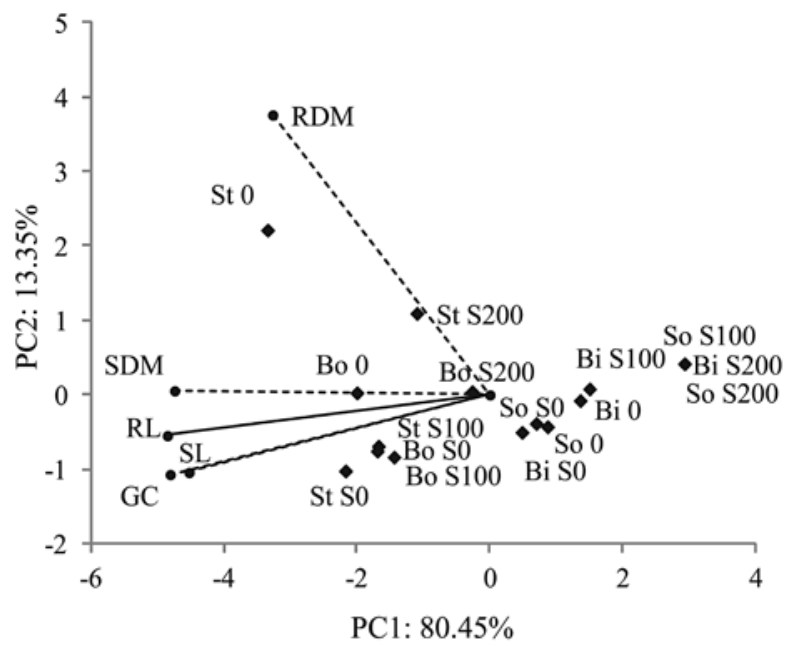

Traits: GC - germination capacity, RL - root length, SL - shoot length, RDM - root dry mass, SDM - shoot dry mass; varieties: Bi - 'Bila', Bo - 'Bokser', So - 'Sójka', St - 'Stadion'; salinity level: $0-0 \mathrm{mM} \mathrm{NaCl}\left(30 / 20^{\circ} \mathrm{C}, 8 / 16 \mathrm{~h}\right), \mathrm{S} 0-0 \mathrm{mM} \mathrm{NaCl}$ $\left(25 / 25^{\circ} \mathrm{C}, 12 / 12 \mathrm{~h}\right), \mathrm{S} 1-100 \mathrm{mM} \mathrm{NaCl}, \mathrm{S} 2-200 \mathrm{mM} \mathrm{NaCl}$

Figure 1. Principal component analysis (PCA) between all traits across cultivars and treatments on different levels of salinity

Effect of drought on seed germination. L. perenne varieties showed similar germination capacity in the conditions without stress as well as in drought simulated by using the solutions of PEG -0.3 and -0.6 MPa (84-96\%) (Table 5). Our results showed that under the highest drought stress of $-1.2 \mathrm{MPa}$ the seeds of both species did not germinate. $P$. pratensis was characterized by lower germination capacity under stress compare to L. perenne. Among the studied varieties 'Bila' showed better germination capacity in applied drought level. Studies presented by Żurek (2006) reported that germination capacity of lawn grass varieties decreased with the increasing of osmotic potential of PEG solutions. Among the tested grasses $L$. perenne distinguished itself by the highest germination capacity, whereas varieties of $P$. pratensis germinated only at $-0.65 \mathrm{MPa}$ and showed neither drought tolerance during seed germination in solutions of negative water potential or drought avoidance mechanism in vegetative stage.

There were found significant differences in MGT of seeds of tested varieties depending on the simulated drought (Table 6). L. perenne varieties showed a similar MGT in the conditions of $0.0 \mathrm{MPa}$ and at drought of -0.3 and $-0.6 \mathrm{MPa}$; however, under the drought of $-1.2 \mathrm{MPa}$ seeds germinated significantly longer, especially of var. 'Bokser'. MGT of $P$. pratensis varieties significantly increased in drought. It was also found that var. 'Sójka' germinated only in $0.0 \mathrm{MPa}$ conditions. Żurek (2006) stated that MGT of seeds of lawn grasses increased with the increasing of the osmotic water potential of PEG solution.

Effect of drought stress on seedlings growth.

There were noticed differences in the length of the shoots and roots of the tested varieties depended on germination conditions (Table 7). There were no marked differences in the length of shoots of all varieties under the $-0.3 \mathrm{MPa}$ level of drought as well as at $0.0 . \mathrm{MPa}$ and variable temperature and light (ISTA Rules, 2014). Whereas under drought of $-0.6 \mathrm{MPa} L$. perenne varieties were characterized by distinctly shorter shoots. It was stated that at osmotic water potential -1.2 MPa seedlings of var. 'Bokser' formed significantly shorter shoots compared to other drought levels (seeds of other varieties did not germinate). Varieties of $P$. pratensis formed less and shorter roots than L. perenne irrespective of germination conditions. In simulated drought, the length of roots of L. perenne was significantly shorter only at $-0.6 \mathrm{MPa}$ and for var. 'Stadion'. Our results showed that under drought conditions $(-0.3$ and $-0.6 \mathrm{MPa}) P$. pratensis formed shorter roots, especially var. 'Sójka'. There was also noticed a significant and positive correlation between the shoot and root length of tested varieties in used germination conditions $(r=0.62, P \leq 0.05)$. 
Table 5. Germination capacity (\%) of Lolium perenne and Poa pratensis varieties in different temperature and light conditions and drought levels

\begin{tabular}{|c|c|c|c|c|c|c|c|c|}
\hline \multicolumn{2}{|c|}{ Germination conditions } & \multirow{2}{*}{$\begin{array}{c}\text { Drought level } \\
\mathrm{MPa}\end{array}$} & \multicolumn{2}{|c|}{ L. perenne } & \multicolumn{2}{|c|}{ P. pratensis } & \multirow{2}{*}{ L. perenne } & \multirow{2}{*}{ P. pratensis } \\
\hline Day/night & Light/dark & & 'Bokser' & 'Stadion' & 'Bila' & 'Sójka' & & \\
\hline $30 / 20^{\circ} \mathrm{C}$ & $8 / 16 \mathrm{~h}$ & 0.0 & 88.7 bcde & $96.0 \mathrm{e}$ & $71.33 \mathrm{f}$ & $86.0 \mathrm{~g}$ & $92.3 \mathrm{E}$ & $78.7 \mathrm{D}$ \\
\hline $25 / 25^{\circ} \mathrm{C}$ & $0 / 24 \mathrm{~h}$ & 0.0 & $86.7 \mathrm{bcd}$ & $94.0 \mathrm{de}$ & $11.3 \mathrm{ab}$ & $0.7 \mathrm{a}$ & $90.3 \mathrm{E}$ & $6.0 \mathrm{~A}$ \\
\hline $25 / 25^{\circ} \mathrm{C}$ & $12 / 12 \mathrm{~h}$ & 0.0 & $84.0 \mathrm{~b}$ & $96.0 \mathrm{e}$ & $57.3 \mathrm{e}$ & $29.3 \mathrm{~cd}$ & $90.0 \mathrm{E}$ & $43.3 \mathrm{C}$ \\
\hline $25 / 25^{\circ} \mathrm{C}$ & $12 / 12 \mathrm{~h}$ & -0.3 & $84.0 \mathrm{~b}$ & 93.3 cde & $40.0 \mathrm{~d}$ & $22.7 \mathrm{bc}$ & $88.7 \mathrm{E}$ & $31.3 \mathrm{~B}$ \\
\hline $25 / 25^{\circ} \mathrm{C}$ & $12 / 12 \mathrm{~h}$ & -0.6 & $85.3 \mathrm{bc}$ & 89.3 bcde & $0.0 \mathrm{a}$ & $2.7 \mathrm{a}$ & 87.3 DE & $1.3 \mathrm{~A}$ \\
\hline $25 / 25^{\circ} \mathrm{C}$ & $12 / 12 \mathrm{~h}$ & -1.2 & $0.0 \mathrm{a}$ & $0.0 \mathrm{a}$ & $0.0 \mathrm{a}$ & $0.0 \mathrm{a}$ & $0.0 \mathrm{~A}$ & $0.0 \mathrm{~A}$ \\
\hline
\end{tabular}

Explanation under Table 1

Table 6. Mean germination time (days) of Lolium perenne and Poa pratensis varieties under drought conditions at $25^{\circ} \mathrm{C}$ and $0 / 24 \mathrm{~h}$ photoperiod

\begin{tabular}{|c|c|c|c|c|c|c|}
\hline \multirow{2}{*}{$\begin{array}{c}\text { Drought level } \\
\mathrm{MPa}\end{array}$} & \multicolumn{2}{|c|}{ L. perenne } & \multicolumn{2}{|c|}{ P. pratensis } & \multirow{2}{*}{ L. perenne } & \multirow[b]{2}{*}{ P. pratensis } \\
\hline & 'Bokser' & 'Stadion' & 'Bila' & 'Sójka' & & \\
\hline 0.0 & $3.4 \mathrm{a}$ & $3.1 \mathrm{a}$ & $6.5 \mathrm{~b}$ & $11.0 \mathrm{~d}$ & $3.3 \mathrm{AB}$ & $8.8 \mathrm{C}$ \\
\hline-0.3 & $3.7 \mathrm{a}$ & $3.4 \mathrm{a}$ & $9.4 \mathrm{c}$ & $0.0 \mathrm{a}$ & $3.6 \mathrm{AB}$ & $4.7 \mathrm{BC}$ \\
\hline-0.6 & $4.4 \mathrm{a}$ & $4.3 \mathrm{a}$ & $10.0 \mathrm{~cd}$ & $0.0 \mathrm{a}$ & 4.4 ABC & $5.0 \mathrm{BC}$ \\
\hline-1.2 & $9.3 \mathrm{c}$ & $7.7 \mathrm{~b}$ & $0.0 \mathrm{a}$ & $0.0 \mathrm{a}$ & $8.5 \mathrm{C}$ & $0.0 \mathrm{~A}$ \\
\hline
\end{tabular}

Explanation under Table 1

Table 7. Morphological features of seedlings of Lolium perenne and Poa pratensis varieties under drought conditions

\begin{tabular}{|c|c|c|c|c|c|c|c|c|}
\hline \multicolumn{2}{|c|}{ Germination conditions } & \multirow{2}{*}{$\begin{array}{c}\text { Drought level } \\
\mathrm{MPa}\end{array}$} & \multicolumn{2}{|c|}{ L. perenne } & \multicolumn{2}{|c|}{ P. pratensis } & \multirow{2}{*}{ L. perenne } & \multirow{2}{*}{ P. pratensis } \\
\hline Day/night & Light/dark & & 'Bokser' & 'Stadion' & 'Bila' & 'Sójka' & & \\
\hline \multicolumn{9}{|c|}{ Shoot length $\mathrm{mm}$} \\
\hline $30 / 20^{\circ} \mathrm{C}$ & $8 / 16 \mathrm{~h}$ & 0.0 & $63.5 \mathrm{~b}$ & $72.1 \mathrm{~cd}$ & $30.7 \mathrm{c}$ & $26.0 \mathrm{~b}$ & $67.8 \mathrm{C}$ & $28.4 \mathrm{~B}$ \\
\hline $25 / 25^{\circ} \mathrm{C}$ & $12 / 12 \mathrm{~h}$ & 0.0 & $75.9 \mathrm{~d}$ & $85.3 \mathrm{ef}$ & $30.5 \mathrm{bc}$ & $34.6 \mathrm{c}$ & $80.6 \mathrm{D}$ & $31.9 \mathrm{~B}$ \\
\hline $25 / 25^{\circ} \mathrm{C}$ & $12 / 12 \mathrm{~h}$ & -0.3 & $77.8 \mathrm{de}$ & $85.9 \mathrm{f}$ & $33.8 \mathrm{c}$ & $29.2 \mathrm{bc}$ & $81.9 \mathrm{D}$ & $32.1 \mathrm{~B}$ \\
\hline $25 / 25^{\circ} \mathrm{C}$ & $12 / 12 \mathrm{~h}$ & -0.6 & $64.5 \mathrm{bc}$ & $63.5 \mathrm{~b}$ & $0.0 \mathrm{a}$ & $27.0 \mathrm{bc}$ & $64.0 \mathrm{C}$ & $13.5 \mathrm{AB}$ \\
\hline $25 / 25^{\circ} \mathrm{C}$ & $12 / 12 \mathrm{~h}$ & -1.2 & $7.7 \mathrm{a}$ & $0.0 \mathrm{a}$ & $0.0 \mathrm{a}$ & $0.0 \mathrm{a}$ & $3.8 \mathrm{~A}$ & $0.0 \mathrm{~A}$ \\
\hline \multicolumn{9}{|c|}{ Root length $\mathrm{mm}$} \\
\hline $30 / 20^{\circ} \mathrm{C}$ & $8 / 16 \mathrm{~h}$ & 0.0 & $65.9 \mathrm{bc}$ & $73.5 \mathrm{~cd}$ & $27.8 \mathrm{~b}$ & $40.1 \mathrm{c}$ & $69.7 \mathrm{D}$ & $33.9 \mathrm{C}$ \\
\hline $25 / 25^{\circ} \mathrm{C}$ & $12 / 12 \mathrm{~h}$ & 0.0 & $63.8 \mathrm{~b}$ & $71.3 \mathrm{bcd}$ & $22.2 \mathrm{ab}$ & $48.5 \mathrm{~d}$ & $67.5 \mathrm{D}$ & $31.1 \mathrm{BC}$ \\
\hline $25 / 25^{\circ} \mathrm{C}$ & $12 / 12 \mathrm{~h}$ & -0.3 & $67.1 \mathrm{bc}$ & $76.6 \mathrm{~d}$ & $21.2 \mathrm{ab}$ & $27.5 \mathrm{~b}$ & $71.9 \mathrm{D}$ & $23.5 \mathrm{AB}$ \\
\hline $25 / 25^{\circ} \mathrm{C}$ & $12 / 12 \mathrm{~h}$ & -0.6 & $67.7 \mathrm{bc}$ & $64.3 \mathrm{~b}$ & $0.0 \mathrm{a}$ & $20.0 \mathrm{ab}$ & $66.0 \mathrm{D}$ & $10.0 \mathrm{AB}$ \\
\hline $25 / 25^{\circ} \mathrm{C}$ & $12 / 12 \mathrm{~h}$ & -1.2 & $11.3 \mathrm{a}$ & $0.0 \mathrm{a}$ & $0.0 \mathrm{a}$ & $0.0 \mathrm{a}$ & $5.7 \mathrm{~A}$ & $0.0 \mathrm{~A}$ \\
\hline \multicolumn{9}{|c|}{ Number of roots } \\
\hline $30 / 20^{\circ} \mathrm{C}$ & $8 / 16 \mathrm{~h}$ & 0.0 & $2.4 \mathrm{e}$ & $2.2 \mathrm{de}$ & $1.0 \mathrm{~b}$ & $1.3 \mathrm{c}$ & $2.3 \mathrm{E}$ & $1.2 \mathrm{BC}$ \\
\hline $25 / 25^{\circ} \mathrm{C}$ & $12 / 12 \mathrm{~h}$ & 0.0 & $2.2 \mathrm{de}$ & $1.9 \mathrm{~cd}$ & $1.1 \mathrm{bc}$ & $1.1 \mathrm{bc}$ & $2.0 \mathrm{DE}$ & $1.1 \mathrm{BC}$ \\
\hline $25 / 25^{\circ} \mathrm{C}$ & $12 / 12 \mathrm{~h}$ & -0.3 & $2.0 \mathrm{de}$ & $1.8 \mathrm{~cd}$ & $1.0 \mathrm{~b}$ & $1.1 \mathrm{bc}$ & $1.9 \mathrm{D}$ & $1.0 \mathrm{AB}$ \\
\hline $25 / 25^{\circ} \mathrm{C}$ & $12 / 12 \mathrm{~h}$ & -0.6 & $1.5 \mathrm{bc}$ & $1.3 \mathrm{ab}$ & $0.0 \mathrm{a}$ & $1.0 \mathrm{~b}$ & $1.4 \mathrm{C}$ & $0.5 \mathrm{AB}$ \\
\hline $25 / 25^{\circ} \mathrm{C}$ & $12 / 12 \mathrm{~h}$ & -1.2 & $1.0 \mathrm{ab}$ & $0.0 \mathrm{a}$ & $0.0 \mathrm{a}$ & $0.0 \mathrm{a}$ & $0.5 \mathrm{AB}$ & $0.0 \mathrm{~A}$ \\
\hline
\end{tabular}

Explanation under Table 1

Table 8. Shoot and root dry mass of seedlings of Lolium perenne and Poa pratensis varieties under drought conditions

\begin{tabular}{|c|c|c|c|c|c|c|c|c|}
\hline \multicolumn{2}{|c|}{ Germination conditions } & \multirow{2}{*}{$\begin{array}{c}\text { Drought level } \\
\mathrm{MPa}\end{array}$} & \multicolumn{2}{|c|}{ L. perenne } & \multicolumn{2}{|c|}{ P. pratensis } & \multirow{2}{*}{ L. perenne } & \multirow{2}{*}{ P. pratensis } \\
\hline Day/night & Light/dark & & 'Bokser' & 'Stadion' & 'Bila' & 'Sójka' & & \\
\hline \multicolumn{9}{|c|}{ Shoot dry mass mg per plant } \\
\hline $30 / 20^{\circ} \mathrm{C}$ & $8 / 16 \mathrm{~h}$ & 0.0 & $5.33 \mathrm{~cd}$ & $5.97 \mathrm{~d}$ & $0.54 \mathrm{bc}$ & $0.64 \mathrm{c}$ & $5.65 \mathrm{D}$ & $0.59 \mathrm{~A}$ \\
\hline $25 / 25^{\circ} \mathrm{C}$ & $12 / 12 \mathrm{~h}$ & 0.0 & $3.18 \mathrm{bc}$ & $5.55 \mathrm{~d}$ & $0.47 \mathrm{bc}$ & $0.71 \mathrm{c}$ & $4.36 \mathrm{C}$ & $0.59 \mathrm{~A}$ \\
\hline $25 / 25^{\circ} \mathrm{C}$ & $12 / 12 \mathrm{~h}$ & -0.3 & $4.29 \mathrm{bcd}$ & $4.75 \mathrm{bcd}$ & $0.47 \mathrm{bc}$ & $0.47 \mathrm{bc}$ & $4.52 \mathrm{CD}$ & $0.47 \mathrm{~A}$ \\
\hline $25 / 25^{\circ} \mathrm{C}$ & $12 / 12 \mathrm{~h}$ & -0.6 & $2.92 \mathrm{~b}$ & $3.04 \mathrm{bc}$ & $0.00 \mathrm{a}$ & $0.20 \mathrm{ab}$ & $2.98 \mathrm{~B}$ & $0.10 \mathrm{~A}$ \\
\hline $25 / 25^{\circ} \mathrm{C}$ & $12 / 12 \mathrm{~h}$ & -1.2 & $0.08 \mathrm{a}$ & $0.00 \mathrm{a}$ & $0.00 \mathrm{a}$ & $0.00 \mathrm{a}$ & $0.04 \mathrm{~A}$ & $0.00 \mathrm{~A}$ \\
\hline \multicolumn{9}{|c|}{ Root dry mass mg per plant } \\
\hline $30 / 20^{\circ} \mathrm{C}$ & $8 / 16 \mathrm{~h}$ & 0.0 & $0.18 \mathrm{a}$ & $0.57 \mathrm{~b}$ & $0.01 \mathrm{a}$ & $0.02 \mathrm{ab}$ & $0.38 \mathrm{~B}$ & $0.02 \mathrm{~A}$ \\
\hline $25 / 25^{\circ} \mathrm{C}$ & $12 / 12 \mathrm{~h}$ & 0.0 & $0.02 \mathrm{a}$ & $0.05 \mathrm{a}$ & $0.06 \mathrm{c}$ & $0.01 \mathrm{a}$ & $0.03 \mathrm{~A}$ & $0.04 \mathrm{~A}$ \\
\hline $25 / 25^{\circ} \mathrm{C}$ & $12 / 12 \mathrm{~h}$ & -0.3 & $0.02 \mathrm{a}$ & $0.07 \mathrm{a}$ & $0.05 \mathrm{bc}$ & $0.03 \mathrm{ab}$ & $0.05 \mathrm{~A}$ & $0.04 \mathrm{~A}$ \\
\hline $25 / 25^{\circ} \mathrm{C}$ & $12 / 12 \mathrm{~h}$ & -0.6 & $0.04 \mathrm{a}$ & $0.03 \mathrm{a}$ & $0.00 \mathrm{a}$ & $0.00 \mathrm{a}$ & $0.04 \mathrm{~A}$ & $0.00 \mathrm{~A}$ \\
\hline $25 / 25^{\circ} \mathrm{C}$ & $12 / 12 \mathrm{~h}$ & -1.2 & $0.00 \mathrm{a}$ & $0.00 \mathrm{a}$ & $0.00 \mathrm{a}$ & $0.00 \mathrm{a}$ & $0.00 \mathrm{~A}$ & $0.00 \mathrm{~A}$ \\
\hline \multicolumn{9}{|c|}{ R: S ratio } \\
\hline $30 / 20^{\circ} \mathrm{C}$ & $8 / 16 \mathrm{~h}$ & 0.0 & $0.03 \mathrm{a}$ & $0.09 \mathrm{~b}$ & $0.02 \mathrm{a}$ & $0.03 \mathrm{ab}$ & $0.06 \mathrm{BC}$ & $0.03 \mathrm{ABC}$ \\
\hline $25 / 25^{\circ} \mathrm{C}$ & $12 / 12 \mathrm{~h}$ & 0.0 & $0.01 \mathrm{a}$ & $0.01 \mathrm{a}$ & $0.13 \mathrm{c}$ & $0.02 \mathrm{a}$ & $0.01 \mathrm{AB}$ & $0.07 \mathrm{C}$ \\
\hline $25 / 25^{\circ} \mathrm{C}$ & $12 / 12 \mathrm{~h}$ & -0.3 & $0.01 \mathrm{a}$ & $0.01 \mathrm{a}$ & $0.10 b c$ & $0.07 \mathrm{abc}$ & $0.01 \mathrm{AB}$ & $0.08 \mathrm{C}$ \\
\hline $25 / 25^{\circ} \mathrm{C}$ & $12 / 12 \mathrm{~h}$ & -0.6 & $0.01 \mathrm{a}$ & $0.01 \mathrm{a}$ & $0.00 \mathrm{a}$ & $0.00 \mathrm{a}$ & $0.01 \mathrm{AB}$ & $0.00 \mathrm{~A}$ \\
\hline $25 / 25^{\circ} \mathrm{C}$ & $12 / 12 \mathrm{~h}$ & -1.2 & $0.00 \mathrm{a}$ & $0.00 \mathrm{a}$ & $0.00 \mathrm{a}$ & $0.00 \mathrm{a}$ & $0.00 \mathrm{~A}$ & $0.00 \mathrm{~A}$ \\
\hline
\end{tabular}

Explanation under Table 1 
Shoot dry mass of seedlings of all varieties and root to shoot $(\mathrm{R}: \mathrm{S})$ ratio achieved higher values in the conditions of variable temperature and light (ISTA Rules, 2014) (Table 8). In our study, significant differences in the shoot dry mass were noted only under $-0.6 \mathrm{MPa}$ compared to $0.0 \mathrm{MPa}$. Simultaneously there was no clear effect of simulated drought on the mass of roots. Our previous pot studies (Mastalerczuk, BorawskaJarmułowicz, 2009), conducted on $P$. pratensis varieties in vegetative stage of growth, have shown that drought stress reduced not only the aboveground mass of plants and number of shoots but also the mass of roots. There were found differences between varieties as well. Results of this study demonstrated that among tested varieties only var. 'Stadion' showed significantly higher mass of roots in the conditions of variable temperature and light (ISTA Rules, 2014) compared with the other treatments. Consequently, the root to shoot ratio of this variety was higher. In our studies, there was no significant correlation between shoot and root mass except var. 'Bila' of $P$. pratensis $(r=-1.00, P \leq 0.05)$ under osmotic potential solution $0.0 \mathrm{MPa}$ at $25^{\circ} \mathrm{C}$ and $12 \mathrm{~h}$ of light.

According to Chaves et al. (2003), root system is a primary element of plant defence strategy against drought. One of important adaptations is the increase of root to shoot ratio with decreasing soil water availability. It is also an element of plant drought resistance strategy known as drought avoidance. Principle component analysis (PCA) in drought conditions showed that the first component (PC1) related to the dry mass of roots retained $80.0 \%$ (Fig. 2).

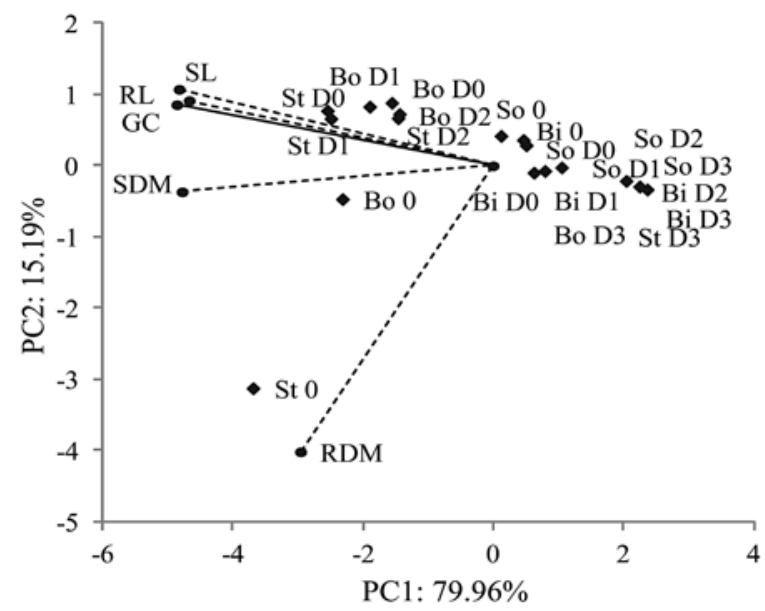

Traits: GC - germination capacity, RL - root length, SL - shoot lenght, RDM - root dry mass, SDM - shoot dry mass; varieties: Bi - 'Bila', Bo - 'Bokser', So - 'Sójka', St - 'Stadion'; drought level: 0 - 0.0 $\mathrm{MPa}\left(30 / 20^{\circ} \mathrm{C}, 8 / 16 \mathrm{~h}\right), \mathrm{D} 0-0.0 \mathrm{MPa}\left(25 / 25^{\circ} \mathrm{C}\right.$, $12 / 12 \mathrm{~h}), \mathrm{D} 1--0.3 \mathrm{MPa}, \mathrm{D} 2--0.6 \mathrm{MPa}, \mathrm{D} 3--1.2 \mathrm{MPa}$

Figure 2. Principal component analysis (PCA) between all traits across cultivars and treatments on different levels of drought

PCA in drought experiment demonstrated similar relations between analyzed traits like in salinity conditions. It was also found that under drought of -0.6 and $-1.2 \mathrm{MPa}$, all studied traits showed small values in varieties of $L$. perenne and $P$. pratensis. There was noticed a significant and positive correlation between the leaf and root length of each variety according to used germination conditions.

\section{Conclusions}

1. Germination capacity of Poa pratensis varieties was modified by light conditions. This species proved to be intolerant of lack of light during seed germination, while Lolium perenne varieties showed tolerance to light conditions in this stage.

2. Salinity increased mean germination time (MGT), decreased germination capacity of seeds, the length of shoots and roots, number of roots and dry mass of shoots of the tested species. L. perenne varieties were more tolerant to salinity stress in comparison to P. pratensis during germination and seedling growth.

3. Drought stress, simulated by using the solutions of polyethylene glycol (PEG), increased MGT, limited germination capacity, shoot and root length and dry mass of $L$. perenne varieties only under the highest $-1.2 \mathrm{MPa}$ drought level, whereas $P$. pratensis even at $-0.3 \mathrm{MPa}$.

4. In the conditions of salinity and simulated drought germination capacity, shoot and root length and the mass of shoots of L. perenne and P. pratensis seedlings were closely correlated to each other.

Received 04072016

Accepted 23112016

\section{References}

Abbassi H., Jamil M., Haq A., Ali S., Ahmad R., Malik Z. Parveen. 2016. Salt stress manifestation on plants, mechanism of salt tolerance and potassium role in alleviating it: a review. Zemdirbyste-Agriculture. 103 (2): 229-238 https://doi.org/10.13080/z-a.2016.103.030

Borawska-Jarmułowicz B., Mastalerczuk G. 2010. 'The influence of the different light time on initial development of $\mathrm{Poa}$ pratensis turf varieties in the first and fourth year after seeds harvest. Grassland Science in Poland, 13: 9-17 (in Polish)

Borowski E. 2008 (a). Studies on the sensitivity of some species and cultivars of lawn grasses on salinity with sodium chloride during the seed germination and first year of growth Folia Horticulturae 20 (1): 81-98 https://doi.org/10.2478/fhort-2013-0108

Borowski E. 2008 (b). Photosynthetic activity of some domestic and foreign cultivars of Lolium perenne L. under conditions of sodium chloride salinity. Acta Agrohotanica, 61 (2): 75-83 https://doi.org/10.5586̆/aa.2008.035

Chai Q., Guo Z. G., Ren J. Z., Nan Z. B. 2006. Assessment of drought resistance of Kentucky bluegrass (Poa pratensis) varieties at seedling stage. New Zealand Journal of Crop and Horticultural Science 34: 319-328 https://doi.org/10.1080/01140671.2006.9514422

Chaves M. M., Maroco J., Pereira J. S. 2003. Understanding plant response to drought - from genes to the whole plant. Functional Plant Riolngy. 30: 239-264 https://doi.org/10.1071/FP02076

Dai J., Hutf D. K., Schlossberg M. J. 2009. Salinity effect on seed germination and vegetative growth of greens-type Poa annua relative to other cool-season turfgrass species. Cron Science, 49: 696-703 https://doi.org/10.2135/cropsci2008.04.0221

Dąbrowski P., Pawluśkiewicz B., Baczewska A. H., Oglęcki P. Kalaji H. 2015. Chlorophyll $a$ fluorescence of perennial ryegrass (Lolium perenne L.) varieties under long term exposure to shade. 7emdirhyste-Agriculture, 102 (3): 305-312 https://doi.org/10.13080/z-a.2015.102.039

Dudley M. M., Jacobi W. R., Brown C. S. 2014. Roadway deicer effects on the germination of native grasses and forhs. Water Air Soil Pollution. 225: 1984 https://doi.org/10.1007/s11270-014-1984-z

Ellis R. H., Roberts E. H. 1980. Towards a rational basis for testing seed quality. Hebblethwaite P. D. (ed.). Seed production. London, UK, p. 605-635

Friell J., Watkins E., Horgan B. 2013. Salt tolerance of 74 turfgrass cultivars in nutrient solution culture. Crop Science 53:1743-1749

https://doi.org/10.2135/cropsci2012.08.0476 
Handbook of Seedling Evaluation. 2013 ( $3^{\text {rd }}$ ed.). International Seed Testing Association (ISTA). Basserdorf, Switzerland, 209 p.

Hardegree S. P., Emmerich W. E. 1994. Seed germination response to polyethylene glycol solution depth. Seed Science and Technology, 22: 1-7

Hujun L., Youzhen G., Jihe W., Mingui H., Zihui Y. 2001. A comparison on salt tolerance of 28 breeds of cold type lawn grass. Acta Prataculturae Sinica, 10 (3): 52-59

ISTA Rules. 2014. International Rules for Seed Testing

Jalali N., Daneshvar N., Shahi-Gharahlar A., Teixeira da Silva J. A., Farhoudi R. 2010. Response of Fescue (Festuca rubra) to salinity sources and levels at seed germination and seedling stage. Seed Science and Biotechnology, 4 (1): 33-36

Khaleghi E., Ramin A. A. 2005. Study of the effects of salinity on growth and development of lawns (Lolium perenne L., Festuca arundinacea and Cynodon dactylon). Journal of Science and Technology of Agriculture and Natural Resources, 9 (3): 57-68

Kusvuran A., Nazli R. I., Kusvuran S. 2015. The effects of salinity on seed germination in perennial ryegrass (Lolium perenne L.) varieties. Turkish Journal of Agricultural and Natural Sciences, 2 (1): 78-84

Mastalerczuk G., Borawska-Jarmułowicz B. 2009. The response of lawn varieties of Poa pratensis to drought stress. $15^{\text {th }}$ international symposium EGF 2009, session 2 . Brno, Czech Republic, p. 414-416

Muns R., Tester M. 2008. Mechanism of salinity tolerance. Annual Review of Plant Physiology, 59: 651-681 https://doi.org/10.1146/annurev.arplant.59.032607.092911

Nizam I. 2011. Effects of salinity stress on water uptake, germination and early seedling growth of perennial ryegrass. African Journal of Biotechnology, 10 (51): 10418-10424 https://doi.org/10.5897/AJB11.1243
Pessarakli M., Kopec D. M. 2009. Screening various ryegrass cultivars for salt stress tolerance. Journal of Food, Agriculture and Environment, 7 (3-4): 739-743

Stawicka J., Wysocki C., Wieczorek J. 2006. The influence of salinity on floral variability of street lawns in Warsaw. Horticulture and Landscape Architecture, 27: 73-81

White P. J., Broadley M. R. 2001. Chloride in soils and its uptake and movement within the plant: a review. Annals of Botanv. 88 (6): 967-988 https://doi.org/10.1006/anbo.2001.1540

Wrochna M., Małecka-Przybysz M., Gawrońska H. 2010. Effect of road de-icing salts with anti corrosion agents on selected plant species. Acta Scientiarum Polonorum Hortorum Cultus, 9 (4): 171-182

Yuan Z., Shi F. 2009. Ecological adaptation strategies in alien species; effects of salinity, temperature and photoperiod on Spartina alterniflora Loisel. seed germination. Polish Journal of Ecology, 57 (4): 677-684

Zhang Q., Rue K. 2012. Glycinebetaine seed priming improved osmotic and salinity tolerance in turfgrasses. HortScience, 47 (8): 1171-1174

Zhang Q., Wang S., Rue K. 2011. Salinity tolerance of 12 turfgrasses in three germination media. HortScience, 46 (4): $651-654$

Zhang H. X., Zhou D. W., Tian Y., Huang Y. X., Sun Z. W. 2012. Comparison of seed germination and early seedling growth responses to salinity and temperature of the halophyte Chloris virgata and the glycophyte Digitaria sanguinalis. Grass and Forage Science, 68: 596-604 https://doi.org/10.1111/gfs.12024

Żurek G. 2006. Grass response to drought stress - evaluation methods and their application to turf species: postdoctoral thesis. Plant Breeding and Acclimatization Institute, Radzików, Poland (in Polish)

ISSN 1392-3196 / e-ISSN 2335-8947

Zemdirbyste-Agriculture, vol. 104, No. 1 (2017), p. 71-78

DOI 10.13080/z-a.2017.104.010

\title{
Lolium perenne bei Poa pratensis jautrumas druskingumui ir sausrai ankstyvuoju vystymosi tarpsniu sèklas daiginant skirtingo fotoperiodo sąlygomis
}

\author{
B. Borawska-Jarmułowicz ${ }^{1}$, G. Mastalerczuk ${ }^{1}$, D. Gozdowski ${ }^{1}$, E. Małuszyńska², A. Szydłowska ${ }^{2}$ \\ ${ }^{1}$ Varšuvos gyvybės mokslų universitetas, Lenkija \\ ${ }^{2}$ Lenkijos augalų selekcijos ir aklimatizacijos institutas - Nacionalinis tyrimų institutas
}

\begin{abstract}
Santrauka
Druskingumas ir sausra yra pagrindiniai veiksniai, ribojantys vejų miglinių žolių daigumą ir augimą. Kontroliuojamomis auginimo sąlygomis ir esant nevienodam paros apšvietimui tirta druskos ir sausros sukelta įtampa daugiametès svidrès (Lolium perenne L.) bei pievinès miglès (Poa pratensis L.) vejų miglinių žolių sẻklų daigumui ir dygimo trukmei, daigų morfologiniams požymiams ir sausai masei. Sèklos daigintos trijų koncentracijų $(0,100$ ir $200 \mathrm{mM})$ natrio chlorido $(\mathrm{NaCl})$ ir keturių koncentracijų $(0,-0,3,-0,6$ ir $-1,2 \mathrm{MPa})$ polietilenglikolio (PEG) tirpaluose, atitinkančiuose keturis sausros streso lygius. Šių nepalankių veiksnių įtaka vertinta esant trims skirtingiems fotoperiodams $(0,8$ ir 12 val. apšvietimo per parą) ir dviem paros temperatūrų sąlygoms (pastovi $25^{\circ} \mathrm{C}$ ir kintanti per parą $-30 / 20^{\circ} \mathrm{C}$ ).

Druskingumas sumažino tirtų rūšių žolių sẻklų daigumą (ịvertintą svidrių po 10 dienų, miglių po 21 dienos), ūglių ir šaknų ilgị, šaknų skaičių bei sausą masę ir pailgino sẻklų vidutinę dygimo trukmę, ypač $P$. pratensis. Sausros stresas pailgino sèklų vidutinę dygimo trukmę ir sumažino daigumą, ūglių bei šaknų ilgị L. perenne sausą masę tik esant didžiausiam (1,2 MPa) sausros lygiui, o P. pratensis - netgi esant sausrai, atitinkančiai $-0.3 \mathrm{MPa}$. Sumodeliuotomis druskingumo ir sausros sąlygomis L. perenne ir P. pratensis daigumas, ūglių bei šaknų ilgis ir daigų masè glaudžiai koreliavo tarpusavyje, o sausros streso sąlygomis L. perenne ir P. pratensis daigų sausa mase buvo mažai susijusi su daigumu, ūglių bei šaknų ilgiu ir daigų mase. Pagal daigumą $P$. pratensis pasirodè neatspari šviesos trūkumui, o L. perenne buvo atspari šviesos stokai.
\end{abstract}

Reikšminiai žodžiai: atsparumas sausrai, daugiametė svidrè, fotoperiodas, gravimetriniai rodikliai, morfologiniai rodikliai, $\mathrm{NaCl}$, polietilenglikolis, pievinè miglè, vejų miglinè žolè. 